\title{
Penentuan Kadar Karbohidrat pada Biji Cempedak Hutan (Artocarpus champeden Lour.) dengan Metoda Tembaga-Iodometri
}

\author{
Neri Fadjria ${ }^{a *}$, Zulfisa ${ }^{a}$, Arfiandia dan Indah Yolandaria \\ aAkademi Farmasi Dwi Farma Bukittinggi
}

\author{
Corresponding Author: \\ Neri Fadjria \\ nerifadjria1607@gmail.com \\ Received: June 2019 \\ Accepted: September 2019 \\ Published: September 2019 \\ CNeri Fadjria et al. This is an \\ open-access article \\ distributed under the terms \\ of the Creative Commons \\ Attribution License, which \\ permits unrestricted use, \\ distribution, and \\ reproduction in any \\ medium, provided the \\ original author and source \\ are credited.
}

\begin{abstract}
Forest Cempedak Seeds (Artocarpus champeden Lour.) Are types of seeds that are underutilized by humans. Forest Cempedak Seed Flour has nutritional content of carbohydrates, fats, and proteins that can be processed as ingredients for food. This study aims to determine the carbohydrate content of Forest Cempedak Seeds (Artocarpus champeden Lour.) Conducted by the Copper-Iodometric method using a luff schoorl reagent. From the research that has been carried out obtained levels of carbohydrates in Cempedak Seeds (Artocarpus champeden Lour.) of $38.016 \%$.
\end{abstract}

Keywords: Artocarpus champeden Lour; Copper-Iodometric; Carbohydrate

\section{Pendahuluan}

Cempedak Hutan (Artocarpus champeden Lour.) merupakan salah satu tanaman buah yang tumbuh liar dapat hidup di daerah tropis. Di Indonesia Cempedak Hutan tersebar luas di Pulau Sumatra, Kalimantan, Sulawesi, Maluku dan Papua Barat. Cempedak Hutan dianggap sama dengan nangka dikarenakan bentuk buahnya yang mirip akan tetapi sebenarnya tekstur daging buahnya lebih kenyal dan manis dibandingkan dengan nangka. Cempedak Hutan juga memiliki aroma buah yang lebih kuat dibandingkan nangka ${ }^{[1]}$. Biji Cempedak Hutan dianggap sebagai limbah yang jarang dikonsumsi oleh masyarakat. Padahal biji cempedak mengandung karbohidrat, protein, lemak dan mineral yang dapat dimanfaatkan sebagai pengganti karbohidrat dalam bentuk tepung dan sumber bioetanol[2].

Penentuan kandungan karbohidrat dapat dilakukan dengan menggunakan metoda spektrofotometri[ ${ }^{[3]}$ dan metoda tembaga- iodometri $^{[4]}$. Meski metoda spektrofotometri jauh lebih praktis, efisien, namun reagen Somogyi-Nelson yang digunakan mengandung arsen[5]. Arsen merupakan logam berbahaya yang keberadaannya tidak boleh dalam lingkungan[6]. Metoda tembaga-iodometri merupakan metoda konvensional yang mengunakan reagen luff schoorl, namun efektif dalam menentukan kadar karbohidrat. Reagen luff schoorl akan bereaksi dengan senyawa monosakarida dan gula pereduksi yang dapat di titrasi dengan menggunakan prinsip iodometri.

\section{Metodologi Penelitian}

\section{Bahan kimia}

Biji Cempedak Hutan (Artocarpus champeden Lour.) yang diperoleh di Kabupaten 50 Kota, Provinsi Sumatera Barat, $\mathrm{CuSO}_{4} .5 \mathrm{H}_{2} \mathrm{O}$, $\mathrm{NaHCO}_{3}, \mathrm{KI}, \mathrm{Na}_{2} \mathrm{CO}_{3}, \mathrm{HCl}, \mathrm{NaOH}, \mathrm{C}_{6} \mathrm{H}_{8} \mathrm{O}_{7} . \mathrm{H}_{2} \mathrm{O}$, $\mathrm{K}_{2} \mathrm{Cr}_{2} \mathrm{O}_{7}, \mathrm{H}_{2} \mathrm{SO}_{4}, \mathrm{Na}_{2} \mathrm{~S}_{2} \mathrm{O}_{3}$, amylum, aquadest. 


\section{Peralatan}

Timbangan analitik, timbangan digital, refluks (Kondesor, labu, penangas air), standar dan klem buret, erlenmeyer, labu ukur, gelas kimia, becker glass, corong, gelas ukur, $\mathrm{pH}$ universal, batang pengaduk, cawan penguap, Pipet volume.

\section{Prosedur penelitian}

\section{Pembuatan reagen}

larutan luff shcoorl

Dilarutkan $25 \mathrm{~g} \mathrm{C}_{6} \mathrm{H}_{8} \mathrm{O}_{7}$. $\mathrm{H}_{2} \mathrm{O}$ dalam $10 \mathrm{ml}$ aqua dest sebagai larutan A, dilarutkan 12,5 gr $\mathrm{CuSO}_{4} .5 \mathrm{H}_{2} \mathrm{O}$ dalam $50 \mathrm{ml}$ aqua dest sebagai larutan B, dilarutkan 71,9 g Na2 $\mathrm{CO}_{3}$ dalam 200 $\mathrm{ml}$ aqua dest mendidih sebagai larutan $\mathrm{C}$. Larutan A dan B yang telah dingin di campur dalam labu ukur $500 \mathrm{ml}$, ditambahkan sedikit demi sedikit larutan $C$, cukupkan dengan aqua dest hingga volume menjadi $500 \mathrm{ml}$, biarkan semalam kemudian disaring ${ }^{[7]}$.

\section{$\mathrm{HCl} \mathrm{3 \%}$}

21,4 $\mathrm{ml} \mathrm{HCl} \mathrm{p}$ dimasukkan ke dalam erlenmeyer $250 \mathrm{ml}$, kemudian ditambahkan aqua dest melalui dinding erlenmeyer sedikit demi sedikit sampai tanda batas.

\section{$\mathrm{NaOH} 40 \%$}

Dilarutkan $4 \mathrm{~g} \mathrm{NaOH}$ dengan aqua dest hingga $10 \mathrm{ml}$.

\section{KI $15 \%$}

Dilarutkan 15 g KI dengan aquadest hingga 100 $\mathrm{ml}$.

\section{$\mathrm{H}_{2} \mathrm{SO}_{4} 25 \%$}

$70 \quad \mathrm{ml} \quad \mathrm{H}_{2} \mathrm{SO}_{4} \quad \mathrm{p}$ dimasukkan kedalam erlenmeyer $250 \mathrm{ml}$, kemudian ditambahkan aqua dest melalui dinding labu ukur sedikit demi sedikit sampai tanda batas.

\section{$\mathrm{Na}_{2} \mathrm{~S}_{2} \mathrm{O}_{3} 0,1 \mathrm{~N}$}

Dilarutkan $13 \mathrm{~g}$ natrium tiosulfat $\mathrm{p}$ dan $100 \mathrm{mg}$ natrium karbonat $p$ kedalam air bebas $\mathrm{CO}_{2}$ hingga $500 \mathrm{ml}$.
Indikator amylum 1\%

Ditimbang amylum $1 \mathrm{~g}$ ditambahkan sedikit demi sedikit aqua dest hingga $100 \mathrm{ml}$, didihkan selama beberapa menit, dinginkan.

Air bebas $\mathrm{CO}_{2}$

Dimasukkan $500 \mathrm{ml}$ aqua dest ke dalam erlenmeyer kemudian tutup. Kemudian panaskan, setelah mendidih buka tutup tersebut hingga $\mathrm{CO}_{2}$ hilang. Kemudian tutup kembali erlenmeyer.

\section{Pengolahan sampel}

Biji Cempedak Hutan dicuci bersih, dikering anginkan, di timbang berat segar, dirajang menjadi bagian-bagian kecil, dijemur hingga kering, dan ditimbang kembali, setelah itu diblender sampai berbentuk tepung dan ditimbang sebanyak 100 gram.

\section{Pembakuan natrium tiosulfat}

$\begin{array}{llllll}\text { Ditimbang seksama } & 700 & \mathrm{mg} & \mathrm{K}_{2} \mathrm{Cr}_{2} \mathrm{O}_{7} & \mathrm{P}\end{array}$ dilarutkan dalam $100 \mathrm{ml}$ 1air dalam labu ukur $100 \mathrm{ml}$, goyangkan hingga larut, kemudian ambil $10 \mathrm{ml}$ larutan $\mathrm{K}_{2} \mathrm{Cr}_{2} \mathrm{O}_{7}$, pindahkan kedalam erlenmeyer, ditambahkan dengan cepat $1 \mathrm{~g} \mathrm{KI} \mathrm{P,} \mathrm{0,7} \mathrm{g} \mathrm{NaHCO}{ }_{3} \mathrm{P}$, dan $5 \mathrm{ml} \mathrm{HCl} \mathrm{P.}$ Tutup erlenmeyer, goyangkan hingga tercampur, biarkan di tempat gelap selama 10 menit. Titrasi dengan larutan $\mathrm{Na}_{2} \mathrm{~S}_{2} \mathrm{O}_{3}$ sampai warna kuning pucat, kemudian tambahkan 3 tetes indikator amylum $1 \%$ dan titrasi dilanjutkan secara perlahan hentikan tepat warna biru menghilang dan muncul warna larutan hijau. lakukan 3 kali pengulangan. catat larutan $\mathrm{Na}_{2} \mathrm{~S}_{2} \mathrm{O}_{3} 0,1 \mathrm{~N}$ yang terpakai ${ }^{[8]}$.

\section{$1 \mathrm{ml}$ natrium tiosulfat 0,1 $\mathrm{N}$ setara dengan $4.904 \mathrm{mg} \mathrm{K}_{2} \mathrm{Cr}_{2} \mathrm{O}_{7}$}

\section{Titrasi blanko}

Dimasukkan $25 \mathrm{ml}$ air ke dalam erlenmeyer, ditambahkan dengan seksama $25 \mathrm{ml}$ larutan luff schoorl, ditambahkan $\mathrm{H}_{2} \mathrm{SO}_{4} 25 \% 25 \mathrm{ml}$ dan ditambahkan $15 \mathrm{ml} \mathrm{KI} 15$ \% sambil erlenmeyer digoyangkan perlahan, dititrasi dengan $\mathrm{Na}_{2} \mathrm{~S}_{2} \mathrm{O}_{3}$ 0,1 N sampai warna putih kecoklatan, kemudian tambahkan $2 \mathrm{ml}$ indikator amylum 1 $\%$ dan titrasi dilanjutkan secara perlahan 
hentikan hingga warna biru tua kehitaman dan larutan berubah warna menjadi putih susu, catat larutan $\mathrm{Na}_{2} \mathrm{~S}_{2} \mathrm{O}_{3} \quad 0,1 \mathrm{~N}$ yang terpakai. Prosedur ini dilakukan 3 kali penggulangan ${ }^{[7]}$.

\section{Penetapan kadar karbohidrat}

Sampel $3 \mathrm{~g}$ dimasukkan ke dalam erlenmeyer ditambahkan $120 \mathrm{ml} \mathrm{HCl} \mathrm{3 \%} \mathrm{direfluk} \mathrm{selama}$ 2,5 Jam. Kemudian didinginkan, setelah itu dinetralkan sampai pH 7 dengan $\mathrm{NaOH} 40 \%$ kemudian diencerkan ke dalam labu ukur 1000 $\mathrm{ml}$. Ambil $25 \mathrm{ml}$ sampel yang telah diencerkan masukkan kedalam erlemeyer dan tambahkan $25 \mathrm{ml}$ luff schoorl, panaskan selama 10 menit. Didinginkan, lalu tambahkan $\mathrm{H}_{2} \mathrm{SO}_{4} \quad 25 \%$ sebanyak $25 \mathrm{ml}$. Ditambahkan lagi KI $15 \%$ sebanyak $15 \mathrm{ml}$. Titrasi dengan larutan $\mathrm{Na}_{2} \mathrm{~S}_{2} \mathrm{O}_{3}$ 0,1 N sampai warna putih kecoklatan, kemudian tambahkan $2 \mathrm{ml}$ indikator amylum 1 $\%$ dan titrasi dilanjutkan secara perlahan hentikan hingga warna biru kehitaman dan sampai larutan titrasi berwarna larutan putih susu, catat larutan $\mathrm{Na}_{2} \mathrm{~S}_{2} \mathrm{O}_{3} 0,1 \mathrm{~N}$ yang terpakai. lakukan 3 kali pengulangan ${ }^{[9]}$.

Kadar Glukosa $=\frac{w 1 \times f p}{w} \times 100 \%$

Kadar karbohidrat $=0,9 \times$ kadar glukosa

Keterangan :

$\mathrm{Fp}=$ faktor pengenceran

$\mathrm{w}=$ berat sampel $(\mathrm{mg})$

$\mathrm{w} 1$ = glukosa yang terkandung untuk tiap $\mathrm{ml}$ $\mathrm{Na}_{2} \mathrm{~S}_{2} \mathrm{O}_{3}$

(Vol. $\mathrm{Na}_{2} \mathrm{~S}_{2} \mathrm{O}_{3}$ blanko - Vol. $\mathrm{Na}_{2} \mathrm{~S}_{2} \mathrm{O}_{3}$ sampel ) $\mathrm{x}$ N. $\mathrm{Na}_{2} \mathrm{~S}_{2} \mathrm{O}_{3} \quad X$ 10Senyawa hasil isolasi dikarakterisasi dengan spektrofotometer UVVis dan IR dimana masing-masing spektrum yang didapatkan dianalisa sehingga didapatkan informasi golongan dan struktur senyawa.

\section{Hasil dan Diskusi}

Biji Cempedak hutan yang telah diserbukkan dihidrolisis dengan pelarut asam karena mudah pengerjaannya dibandingkan dengan menggunakan enzim. Pelarut asam yang digunakan adalah $\mathrm{HCl}$ 3\% yang merupakan konsentrasi optimum dalam menghidrolisis. Serbuk yang sudah terbentuk di hidrolisis dengan menggunakan alat refluk selama 2,5 jam. Refluk adalah teknik destilasi yang melibatkan kondensasi uap berbalik kondesat ke dalam sistem awalnya ${ }^{[10]}$. 2,5 jam merupakan waktu yang optimum untuk menghidrolisis dalam mengubah senyawa polisakarida menjadi senyawa gula pereduksi dan monosakarida. Jika waktu melebihi waktu optimum, akan menyebabkan monosakarida yang terbentuk akan menjadi rusak ${ }^{[11]}$.

Hasil hidrolisis di analisa secara kualitatif dan kuantitatif. Pengujian tahap kualitatif dapat dilihat dalam Tabel 1. Tabel 1 menunjukkan hasil hidrolisis telah sempurna dimana pengujian kualitatif hasil hidrolisis dengan menggunakan iodin test membentuk hasil yang negatif terhadap reagen iodin, Reaksi Hidrolisis tersebut dipengaruhi oleh adanya katalisator, temperatur, dan kadar pada Biji Cempedak Hutan. Pelarut asam berfungsi mempercepat jalannya suatu reaksi, semakin tinggi kosentrasi katalis asam maka proses hidrolisis semakin cepat sehingga glukosa yang diperoleh akan semakin tinggi. Reaksi juga dipercepat dengan bantuan pemanasan selama hidrolisis [11].

Hasil proses hidrolisis yang telah didinginkan dinetralkan dengan $\mathrm{NaOH}$ untuk mendapatkan hasil yang optimal. Penentuan kadar karbohidrat dilakukan pada $\mathrm{pH}$ netral. Dalam pengujian ini $\mathrm{pH}$ larutan harus diperhatikan dengan baik, karena $\mathrm{pH}$ yang terlalu rendah (terlalu asam) akan menyebabkan Volume pentiter menjadi meningkat dari sebenarnya sehingga kadar yang diperoleh menjadi rendah. Sedangkan apabila $\mathrm{pH}$ terlalu tinggi (terlalu basa), maka volume pentiter akan menjadi sedikit terpakai daripada sebenarnya sehingga kadar menjadi tinggi.

Dalam pembuatan $\mathrm{Na}_{2} \mathrm{~S}_{2} \mathrm{O}_{3}$ ditambahkan natrium karbonat dengan tujuan sebagai pengawet ${ }^{[12]}$. Pada proses pembuatan reagen luff schoorl natrium karbonat dimasukkan perlahan-lahan bertujuan agar tidak tertumpah reagen pada labu ukur dikarenakan pada waktu pemberian akan melepaskan gelembung gas $\mathrm{CO}_{2}$. 
Tabel 1. Uji kualitatif karbohidrat

\begin{tabular}{lcc}
\hline $\begin{array}{l}\text { Serbuk Biji Cempedak } \\
\text { Hutan }\end{array}$ & Reagen iodine test & Reagen luff schoorl \\
\hline Sebelum Hidrolisis & Biru Kehitaman & Tidak terjadi perubahan \\
Setelah Hidrolisis & Tidak Berwarna & warna \\
\hline
\end{tabular}

Reaksi jika ada $\mathrm{CO}_{2}$ dalam larutan $\mathrm{Na}_{2} \mathrm{~S}_{2} \mathrm{O}_{3}$

$$
\mathrm{Na}_{2} \mathrm{~S}_{2} \mathrm{O}_{3}+\mathrm{CO}_{2}+\mathrm{H}_{2} \mathrm{O} \rightarrow \mathrm{NaHCO}_{2}+\mathrm{NaHSO}_{3}+\mathrm{S} \downarrow
$$

Larutan yang diperoleh akan menjadi keruh serta efek reaksinya penguraian $\mathrm{Na}_{2} \mathrm{~S}_{2} \mathrm{O}_{3}$ dengan adanya $\mathrm{CO}_{2}$ akan meningkatkan kosentrasi larutan, hal ini menyebabkan penyimpangan pemakaian larutan [12]. Tahap awal pada pembakuan $\mathrm{Na}_{2} \mathrm{~S}_{2} \mathrm{O}_{3}, \quad \mathrm{~K}_{2} \mathrm{Cr}_{2} \mathrm{O}_{7}$ ditambahkan asam klorida pekat, natrium bikarbonat, dan KI. KI yang ditambahkan dalam pembakuan harus dilebihkan agar $\mathrm{I}_{2}$ terbentuk sempurna. lalu didiamkan selama 10 menit ditempat yang gelap dan selanjutnya dititrasi dengan $\mathrm{Na}_{2} \mathrm{~S}_{2} \mathrm{O}_{3}$ terbentuk warna hijau tua.

Reaksi Kimia Pembakuan $\mathrm{Na}_{2} \mathrm{~S}_{2} \mathrm{O}_{3}$ dengan $\mathrm{K}_{2} \mathrm{Cr}_{2} \mathrm{O}_{7}$ :

$\mathrm{K}_{2} \mathrm{Cr}_{2} \mathrm{O}_{7}+6 \mathrm{KI}+14 \mathrm{HCl} \rightarrow 8 \mathrm{KCl}+2 \mathrm{CrCl}_{3}+3 \mathrm{I}_{2}$ $+7 \mathrm{H}_{2} \mathrm{O}$

$\mathrm{I}_{2}$ (berlebih) $+\mathrm{Na}_{2} \mathrm{~S}_{2} \mathrm{O}_{3} \longrightarrow \mathrm{Na}_{2} \mathrm{~S}_{4} \mathrm{O}_{6}+2 \mathrm{NaI}^{[13]}$

Penambahan indikator amylum dilakukan saat mendekati titik akhir agar iod berikatan dengan amylum yang sukar dipecah dan tidak kembali ke senyawa semula. Setelah penambahan amylum akan merubah warna menjadi biru kehitaman karena adanya ikatan $I_{2}$ dengan amylum lalu dititrasi kembali sehingga terbentuk warna hijau (titik akhir). Analisa penentuan kadar dimulai dengan menggunakan hidrolisis Biji Cempedak Hutan yang sudah netral diencerkan dengan aqua dest. Hasil hidrolisis ditambahkan reagen luff shcoorl dipanaskan selama 10 menit munculnya endapan merah bata karena luff schoorl mereduksi ion $\mathrm{Cu}{ }^{+2}$ menjadi $\mathrm{Cu}^{+}$yang menandakan adanya karbohidrat pada Biji Cempedak Hutan. Seperti reaksi dibawah ini:

$\mathrm{R}-\mathrm{COH}+2 \mathrm{CuO}$ berlebih $\rightarrow \mathrm{R}-\mathrm{COOH}+\mathrm{Cu}_{2} \mathrm{O}$ $+\mathrm{CuO}$ sisa[14]

Proses pemanasan 10 menit bertujuan agar proses reduksi berjalan sempurna sehingga terbentuk warna endapan merah bata. Di dalam endapan merah bata terdapat $\mathrm{CuO}$ sisa yang ditandai dengan masih adanya warna biru luff schoorl yang akan di titrasi. Lalu tambahkan $\mathrm{H}_{2} \mathrm{SO}_{4}$ dan $\mathrm{KI}$ dengan reaksi sebagai berikut:

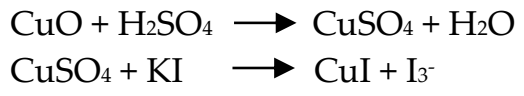

Ion tri iodida yang bebas ini selanjutnya akan dititrasi dengan larutan standar $\mathrm{Na}_{2} \mathrm{~S}_{2} \mathrm{O}_{3}$. Dengan reaksi

$\mathrm{I}_{3}{ }^{-}+2 \mathrm{~S}_{2} \mathrm{O}_{3}{ }^{-2} \longrightarrow 3 \mathrm{I}^{-}+\mathrm{S}_{4} \mathrm{O}_{6}{ }^{-2}[15]$

Dengan menambahkan $\mathrm{Na}_{2} \mathrm{~S}_{2} \mathrm{O}_{3}$ berlebihan kepada larutan ion tri-iodida direduksi menjadi ion iodida yang tak berwarna, sehingga endapan tersebut berwarna putih susu. Penambahan Indikator amilum dilakukan pada saat mendekati titik ekivalen sampai warna biru kehitaman.

Dari hasil penelitian yang dilakukan diperoleh kadar karbohidrat dari serbuk biji cempedak hutan sebesar 38,016\% dengan menggunakan rumus perhitungan berdasarkan SNI 01-28911992 [16]. Kadar karbohidrat yang di peroleh dipengaruhi oleh beberapa faktor seperti iklim/ cuaca, kesuburan tanah dan daerah tempat tumbuhnya tanaman cempedak hutan serta dipengaruhi oleh proses hidrolisis yaitu waktu dan kosentrasi $\mathrm{HCl}$ pada saat menghidrolisis [11]. Penentuan kadar karbohidrat dapat diteliti 
lebih lanjut dengan perbedaan konsentrasi $\mathrm{HCl}$ yang berbeda untuk memperoleh kadar karbohidrat biji cempedak lebih optimal.

\section{Kesimpulan}

Dari hasil penelitian yang telah dilakukan pada penentuan kadar karbohidrat pada Biji Cempedak Hutan (Artocarpus champeden Lour.) menggunakan metoda luff schoorl didapat kadar sebesar 38,016 \%.

\section{Daftar Pustaka}

1. Zerega, N. J. C., Ragone, D. \& Motley, T. J., Complex origins of breadfruit (Artocarpus altilis, Moraceae): implications for human migrations in Oceania. Am. J. Bot., 91(5): 760-766 (2004).

2. Santoso, W. T. \& Kartika, R., Pembuatan Etanol Dari Biji Cempedak (Artocarpus champeden sp.) Dengan Hidrolisis Menggunakan Enzim Alfa Amilase Dan Glukolase Fermentasi Saccharomyces cerevisiae. J. Kim. Mulawarman, 13(2): (2016).

3. Albalasmeh, A. A., Berhe, A. A. \& Ghezzehei, T. A., A new method for rapid determination of carbohydrate and total carbon concentrations using UV spectrophotometry. Carbohydr. Polym., 97(2): 253-261 (2013).

4. Galant, A. L., Kaufman, R. C. \& Wilson, J. D., Glucose: Detection and analysis. Food Chem., 188: 149-160 (2015).

5. Puspawati, S., Ainuri, M. \& Nugraha, D. A., The production of bioethanol fermentation substrate from Eucheuma cottonii seaweed through hydrolysis by cellulose enzyme. Agric. Agric. Sci. Procedia, 3: 200-205 (2015).

6. Rahman, Z. \& Singh, V. P., The relative impact of toxic heavy metals (THMs) (arsenic (As), cadmium (Cd), chromium $(\mathrm{Cr})(\mathrm{VI})$, mercury $(\mathrm{Hg})$, and lead $(\mathrm{Pb}))$ on the total environment: an overview. Environ. Monit. Assess., 191(7): 419 (2019).

7. Maretta, V., Pemanfaatan Daun Stevia (Stevia rebaudiana) sebagai Pemanis Alami terhadap Kualitas Organoleptik dan Kadar Gula Total Bolu Kukus. (2012).

8. Indonesia, D. K. R., Farmakope Indonesia edisi ke-3. DepKes RI, Jakarta, (1979).

9. Agusandi., Supriadi, A. \& Lestari, S. D., Pengaruh Penambahan Tinta Cumi-cumi (Loligo sp) terhadap Kualitas Nutrisi dan Penerimaan Sensoris Mi Basah. J. Fishtech, 2(1): 22-37 (2013).

10. Fairus, S., Haryono Miranthi, A. \& Aprianto, A., Pengaruh Konsentrasi HCL dan waktu hidrolisis terhadap perolehan glukosa yang dihasilkan dari pati biji nangka. in Jurnal Prosiding Seminar Nasional Teknik Kimia, (2010).

11. Mardina, P., Prathama, H. A. \& Hayati, D. M., Pengaruh waktu hidrolisis dan konsentrasi katalisator asam sulfat terhadap sintesis furfural dari jerami padi. J. Konversi UNLAM, 3(2): 1-8 (2014).

12. HAM, M., Pembuatan Reagen Kimia di Laboratorium. (2006).

13. Day, R. A. (Reuben A. \& Underwood A. L. (Arthur Louis), 1924-., Analisa kimia kuantitatif. Jakarta : Erlangga, (1994).

14. Sudarmadji, S., Suhardi. \& Haryono, B., Analisa bahan makanan dan pertanian. Liberty Yogyakarta bekerja sama dengan Pusat Antar Universitas Pangan dan Gizi Universitas Gadjah Mada, (1989).

15. Vogel, A. I. \& Svehla, G., Analisis Anorganik Kualitatif Makro dan Semimikro. Penterjemah Sutiono, L., Hadyana, Pujaabmaka. Jakarta Kalman Media Pustaka, (1985).

16. Indonesia, S. N., Cara Pengujian Makanan dan Minuman. Direktorat Pengolah. dan Pemasar. Has. Peternak. Dep. Pertanian.[SNI No. 01-2891-1992]. Jakarta, (1992). 